\title{
A GOLPE DE RETINA: FORMACIÓN Y CONCIENCIACIÓN DEL 'NUEVO ESTADO' A TRAVÉS DE LA IMAGEN
}

Penélope Ramírez Benito

Universidad de La Rioja

RESUMEN: La imagen nunca es inocente, y su propósito parte de aquellos que la crean o la encargan. En este artículo podremos ver a través de la cartelística, los diferentes tipos de publicaciones gráficas, la retratística del Jefe del Estado y otras personalidades, el cine y el Noticiario Documental (NO-DO), cómo el régimen franquista trató de imponer una educación visual para generar una opinión pública asentando así los valores del Nuevo Estado.

Palabras clave: Imagen, opinión pública, Franco, Nuevo Estado, Servicio Nacional de Prensa y Propaganda, Ley Serrano Súñer, cartelística, publicaciones gráficas, retratística, cine, Noticiario Documental (NO-DO), valores.

ABSTRACT: The image is never innocent, and its purpose belongs to those who have created or have entrusted it. In this article we will see through the cartelistic, the different typologies of graphic publications, the portraits of the Head of the State and other personalities, and the cinema as well as the Documentary Newscast (NO-DO), how Franco's regime treated to impose a visual education to generate a unified public opinion, formalizing this way the New State's values.

Keywords: Image, public opinion, Franco, New State, National Service of Press and Propaganda, Serrano Suñer's Act, cartelistic, graphic publications, portraits, cinema, Documentary Newscast (NO-DO), values. 


\section{Introducción}

Puesto que ninguna imagen está libre de intenciones, como bien dio a entender el profesor Peter Burke', pues todas, y con más razón las que han sido encargadas, conllevan cierta intencionalidad añadida. Así ha ocurrido y sigue ocurriendo en los regímenes políticos de corte autoritario, ya que llegado el momento de su afianzamiento, necesitan de una escenografía propia que les acompañe e identifique allá donde vayan y, por supuesto, en el lugar en el que se desarrollan. El caso particular del régimen franquista no podía ser una excepción a esta máxima, sobre todo teniendo en cuenta experiencias anteriores en el tiempo como el fascismo italiano y el nazismo alemán, que le sirvieron de base para todo un trabajo de formación de la opinión pública.

El caso particular del que nos vamos a ocupar será el de la importancia de la imagen contemporánea al franquismo, tanto durante la guerra, como en su primera etapa una vez concluida la contienda (1939-1959), para su asentamiento en la mentalidad colectiva y el adoctrinamiento de ésta, y aunque las imágenes de este periodo son bastante numerosas, se pueden agrupar en grandes categorías que irán en función de su facilidad de alcance a las clases populares. Por tanto, tenemos la cartelística; las publicaciones de tipo gráfi$\mathrm{co}$, en las cuales pesa más la imagen que el texto debido al alto índice de analfabetismo entre la población española; las representaciones y retratos oficiales del Jefe del Estado y otras personalidades del régimen; y, por último, el cine y el NO-DO.

Todos estos elementos conformaron, o por lo menos lo intentaron, la ideología de la sociedad de este país cerca de cuarenta años, aunque no podemos olvidar que la mayor presión se ejerció en la etapa de posguerra. Otra nota característica común a todos ellos es que pueden ser considerados como medios de masas y que, aún hoy, perduran en una memoria colectiva, bien por haberlos vivido, o bien "de oídas". Pero lo importante es no olvidarlos, no por los mensajes emitidos, cada vez más lejanos, sino porque la imagen nunca es inocente.

\section{La cartelística}

Debido a la importancia de la cartelística como documento histórico para el seguimiento del comienzo de la guerra civil y su final, así como de la evolución de la ideología franquista a lo largo del desarrollo del régimen, cabe dar, debido a las confusiones que pueden generar en la distinción entre las hojas volanderas y escritos impresos con los verdaderos carteles, una serie de pautas identificati-

1. Burke, P., Visto y no visto. El uso de la imagen como documento histórico, Barcelona, Crítica, 2001. 
vas de lo que es un auténtico cartel según Juan Antonio Ramírez, para después introducirnos en la temática franquista²:

a) En todo cartel hay un mensaje icónico o icónico-literario. Los carteles sin imagen no se pueden denominar como tales, pues entrarían dentro del género del anuncio mural. Siendo así, podremos encontrar un cartel sin palabras, pero nunca sin imagen.

b) El soporte del mensaje será plano y, por lo general, de poca consistencia (papel generalmente). Esto se debe a que no hay vocación de permanencia y será pronto sustituido por otro cartel-otro mensaje. Es precisamente esta cualidad lo que distingue al cartel de la pintura, lo cual explica que, aunque haya pasado un corto espacio de tiempo entre las primeras épocas de la cartelística y hoy, jamás podremos analizar su número en totalidad.

c) La combinación imagen-texto no tiene un carácter único, sino múltiple. Es decir, el original de un cartel no puede tener sentido si no es para la obtención de un gran número de copias. Hay que señalar que, dedicándonos en este apartado a un medio de masas como es el cartel, este cumplirá el requisito de llevar el mensaje al mayor número de personas posibles sin variarlo en ningún momento, lo que quiere decir que no habrá distinción alguna entre las copias salidas del original.

d) El cartel tendrá casi siempre un tamaño grande, aunque hay excepciones en la primera época del franquismo dada la carestía de papel que se inició en la guerra y que perdurará durante un tiempo ya impuesta la paz. No obstante, habrá que diferenciar suficientemente al cartel del anuncio periodístico, revistas ilustradas, programas de mano del cine... Pero si en algo se parecerá el cartel en su función a la del cine, siendo posible deducirlo de este subapartado, será en su perspectiva de colectividad, pues los dos están orientados hacia la masa.

e) En relación con el anterior requisito, nos hallaremos ante la tendencia a la simplificación formal debido a la necesidad de atraer las miradas. Además, para que un cartel ejerza de transmisor de un mensaje a una serie de receptores, éste debe ser captado por el espectador de manera casi instantánea. Por tanto, no interesan complicaciones que entorpezcan la claridad deseada, por ejemplo, no podemos imaginar un cartel anticomunista de guerra y de posguerra con un estilo art noveau, pues sería incoherente y entorpecería el mensaje con sus filigranas. Hablamos, pues, de un caso de practicidad y coherencia.

2. Ramírez, J. A., Medios de masas e historia del arte, Barcelona, Cátedra, 1992, pp. 182183. 
Una vez vistos y estudiados estos requisitos, nos dedicaremos ya con cierta seguridad al estudio de lo que realmente se puede considerar como cartelística y escogeremos los ejemplares más significativos para analizar, desde cómo se van avanzando posiciones durante la guerra, pues según sea así iremos contando con más nombres de industrias gráficas, hasta cómo aumenta la calidad de los dibujantes al tener más medios a su alcance.

La temática del cartel franquista se puede dividir en siete materias distintas, solapadas en el tiempo, y que abarcarán todos los ámbitos ideológicos y de la vida para mayor influencia de la masa que se verá dominada en todas sus esferas cotidianas ${ }^{3}$ :

1. El cartel en el bando nacional.

2. Franco y la Victoria.

3. La Falange y su doctrina.

4. La España de Franco.

5. Espectáculos, ferias y fiestas.

6. La propaganda nacional-sindicalista en el taller y la industria.

7. Iglesia, educación y capacitación en la posguerra.

Aunque realmente toda esta variedad temática se podría englobar, y simplificar -si es que esto es posible en un tema tan complicado como la cartelísticadentro de dos subapartados que serían:

1. Carteles de guerra.

2. Victoria del bando franquista.

En el primer caso, es donde queda más patente el ya comentado avance de las tropas franquistas a lo largo de la geografía española, pues no será igual un cartel de 1937 que de finales de 1938, pues por lo general, el más temprano será de menor calidad, tanto por el papel como por las tintas usadas, aunque esta cuestión de las tintas será la que en mayor proporción aumente su mejora respecto a las calidades de los diversos conformantes de un cartel.

Las primeras imprentas se localizaron en Zaragoza (Litografías Industrias del Cartonaje y Gráficas Portabella) y Tolosa (Litografías Laborde y Labayen) para después ampliar su número con el transcurso del tiempo. En cuanto a los principales cartelistas, podemos mentar a Juan Cabanas, Teodoro Delgado, José

3. Carulla, J. y Carulla, A., La Guerra Civil en dos mil carteles, Vol II, Barcelona, Postermil, 1997, pp. 526 y ss.

4. Carulla, J. y Carulla, A., La Guerra..., pp. 532 y ss. 
Caballero y Carlos Sáenz de Tejada, lo que no quiere decir que no haya más, sino que caben ser destacados por la calidad artística de sus carteles en relación con la escasez de medios de los que se disponía ${ }^{5}$.

Por lo que respecta a los temas de los carteles, no se ve mucha variedad, pudiéndolos dividir entre soldadescos, y de cruzada, siendo los más curiosos los dedicados al Día del Plato Único (figuras.1, 2 y 3).
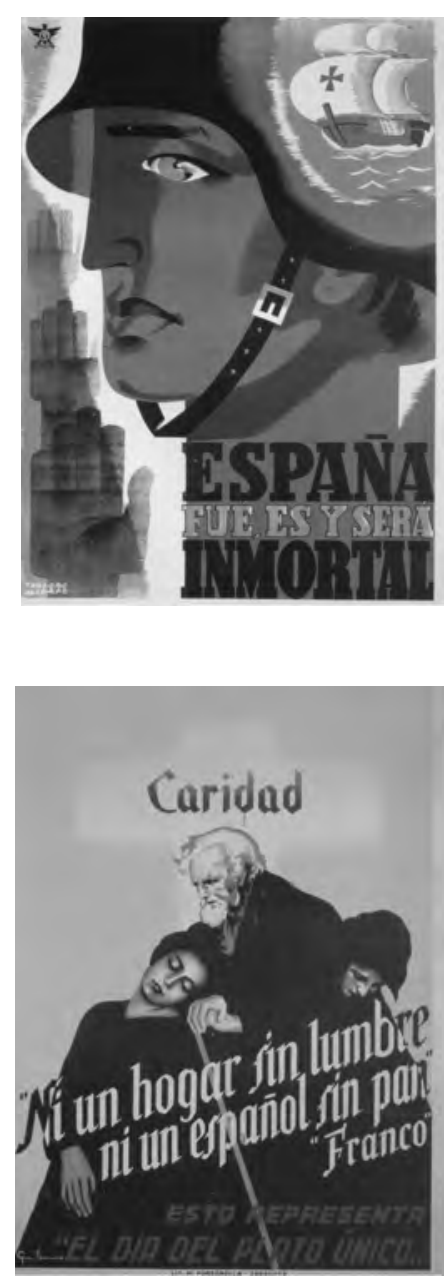

Fig. 1. Cartel de Teodoro Delgado. 1937. No consta su lugar de edición. Tamaño: 100x70. Fuente: Carulla, J. y Carulla, A., La Guerra Civil en dos mil carteles, Vol II,Barcelona, Postermil, 1997, p. 533.
Fig. 2. Autor: Guillermo. 1938 Gráficas Portabella. Zaragoza. 85x61. Fuente: Carulla, J. y Carulla, A., La Guerra Civil en dos mil carteles, Vol II, Barcelona, Postermil, 1997, p. 543.

5. Respecto a Juan Cabanas y otros cartelistas vemos a BOZAL, V., Summa Artis. Pintura y escultura españolas del siglo XX (1900-1939), Vol. XXXVI, Madrid, Espasa-Calpe, 1992, pp. 661-662. 


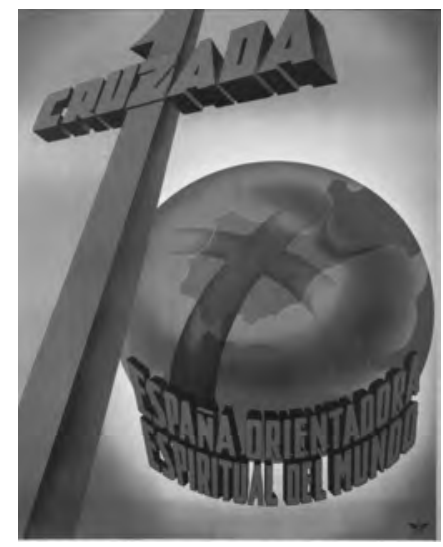

Fig. 3. Anónimo. 1937

Editó: Servicio Nacional

de Propaganda (SNP) a

cargo del Departamento

de Plástica. 100x70.

Fuente: Carulla, J. y

Carulla, A., La Guerra

Civil en dos mil carteles,

Vol II, Barcelona,

Postermil, 1997, p. 542.

Ya en el segundo caso, y con la paz impuesta en España por el bando nacional, la calidad técnica de los carteles irá aumentando paulatinamente, pues las mejores industrias de impresión se encontraban en Valencia (Gráficas Ortega, Gráficas Mirabet...), Barcelona (Seix \& Barral...), Valladolid (Gráficas Afrodisio Aguado), Madrid (Rivadeneyra...) y Vitoria (Gráficas Heraclio Fournier) ${ }^{6}$, etc. Por lo que respecta a los cartelistas, seguirán los anteriormente nombrados excluyendo a Sáenz de Tejada que no hizo más que dos magníficos carteles para Auxilio Social (anteriormente Auxilio de Invierno) antes de finalizar la guerra, y que devendrá por otros derroteros más apropiados a su orientación artística.

Es precisamente en esta etapa, tras la victoria, cuando comienza una verdadera campaña de culto al líder, en este caso "caudillo", exaltando la personalidad de Francisco Franco y venerando a José Antonio Primo de Rivera como fundador de la Falange.

No es de extrañar, que con los antecedentes de las dictaduras de Mussolini y Hitler en Europa, Franco tratase de buscar y, de hecho, encargó que le fuese buscado, algún gesto característico que le identificase, como pudo ser la poderosa mandíbula del dictador italiano o el peculiar bigote y mirada encendida del alemán. Pues bien, si por algo resultó Franco totalmente identificado fue por su sonrisa según el testimonio escrito de Giménez Caballero, datado en 1938 (se buscó esta reafirmación mediante identificación incluso antes del final de la guerra) y titulado, cómo no, La sonrisa de Franco, publicado en la revista Los combatientes, de la cual podemos extractar: "FRANCO (sic) es la sonrisa. Su más profundo secreto. No estamos conformes con los retratos que pintan de

6. Carulla, J. y Carulla, A., La Guerra..., pp. 544 y ss. 
FRANCO: serio, cejijunto, grave, doctoral. Como para darle un aire mussoliniano o hitlerista (...)" (fig. 4).

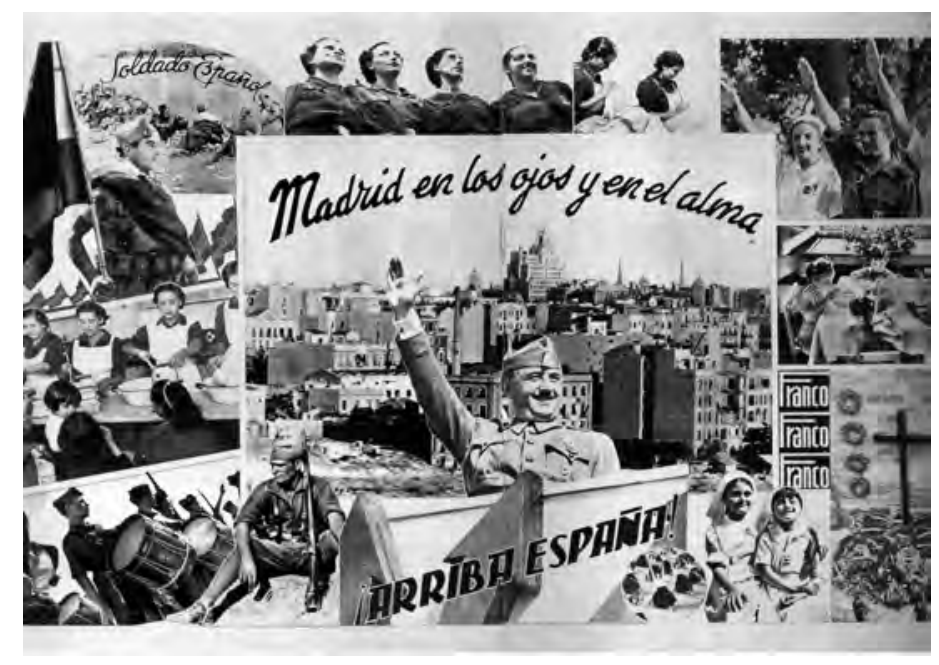

Fig. 4. Fotomontaje. 1939. 1939. No consta lugar de impresión ni a cargo de quién. Fuente: Carulla, J. y Carulla, A., La Guerra Civil en dos mil carteles, Vol II, Barcelona, Postermil, 1997, p. 546.

Aunque realmente, según Carmen Grimau en su estudio de la cartelística política y, concretamente, de la imagen de Franco en ésta, Ilegó a la conclusión de que "su postura es rígida, cohibida, su mirada lacónica e indefinible; el conjunto traduce una sensación de atrofia física y mental, tal vez acentuada por la estereotipación de la imagen, carente de la menor agilidad imaginativa" ${ }^{\prime 8}$. Nada más alejado de la sonrisa que preconizó Giménez Caballero.

Por lo que se refiere a José Antonio Primo de Rivera, sus retratos lo representarán siempre en cabeza, busto o torso, con una clara idealización de la imagen, en la que profundizaremos más adelante al tratar sobre la retratística, y casi

7. Cirici, A., La estética del franquismo, Barcelona, Gustavo Gili, 1977, pp. 76 y ss. Acerca de Giménez Caballero y su escrito La sonrisa de Franco recomendamos la lectura de Santonja, G., De un ayer no tan lejano. Cultura y propaganda en la España de Franco durante la guerra y los primeros años del Nuevo Estado, Madrid, NOESIS, 1996, pp. 16-18.

8. Grimau, Carmen, "Cartel político y publicidad comercial", Bonet, A. (coord.), Arte del Franquismo, Madrid, Cátedra, 1981, p. 278. 
siempre acompañado de alguna frase lapidaria referente a la correcta actuación del buen falangista (fig. 5).

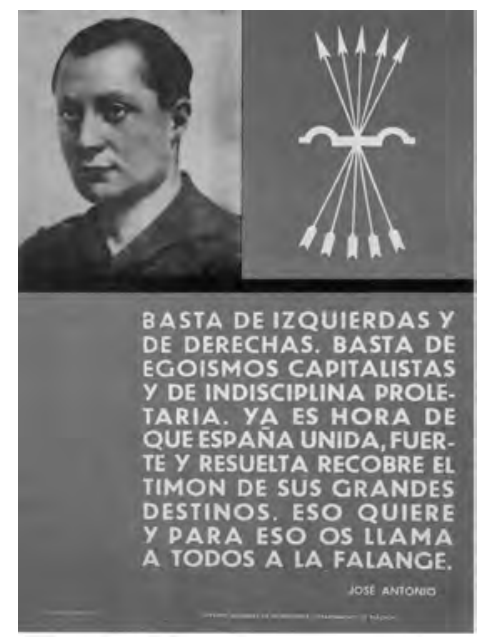

Fig. 5. Tipo-foto. 1940. S. G. de publicaciones. SNP y DP. 49x34. Fuente: Carulla, J. y Carulla, A., La Guerra Civil en dos mil carteles, Vol II, Barcelona, Postermil, 1997, p. 566.

Todos los carteles editados a partir de 1938 dependerán del Servicio de Nacional de Prensa y Propaganda y, en concreto, del Departamento de Plástica, cuyo primer director será Juan Cabanas, nombrado ya como cartelista fundamental. Posteriormente, se publicaron colecciones de carteles por el Ministerio de Educación y la Dirección General de Bellas Artes, organizándose tanto en España como en el extranjero exposiciones dirigidas por Eugenio $\mathrm{D}^{\prime} \mathrm{Ors}^{9}$.

\section{Publicaciones gráficas}

Es en enero de 1938, antes de finalizar la guerra, cuando asistimos al nacimiento del Servicio Nacional de Prensa y Propaganda, que dependerá del Ministerio de Gobernación, dándole sus contenidos (inspirados en las normas fascistas italianas) la Ley Serrano Súñer el 24 de abril de ese mismo año: "Incumbe al Estado la organización, vigilancia y control de la institución nacio-

9. Carulla, J. y Carulla, A., La Guerra... p. 526. Para más información sobre la política institucional sobre la imagen propagandística se recomienda la lectura de Llorente, Á., "La propaganda por la imagen y el arte en la posguerra. La Comisión de Estilo en las conmemoraciones de la Patria y el departamento de Plástica entre 1939-1945", Tusell, J., Sueiro, S., Marín, J. M., Casanova, M. (coords.), El régimen de Franco (1939-1975). Congreso Internacional Madrid, Mayo 1993, Tomo II, Madrid, UNED, 1993, pp. 453-462. 
nal de la Prensa periódica. En este sentido compete al Ministro encargado del Servicio Nacional de Prensa la facultad ordenadora de la misma"10.

No es pues de extrañar que la prensa, usada como elemento propagandístico del nuevo orden, fuese algo necesariamente controlado por las más altas jerarquías políticas ${ }^{11}$. Aquí, nos referiremos a esta prensa pero dedicando toda nuestra atención a la de mayor contenido gráfico, dividiendo este punto en dos partes:

a) Publicaciones infantiles.

b) Publicaciones para adultos.

Es a partir de los años 40, cuando vemos especial atención en las publicaciones para niños y adolescentes, pues desde el mismo Estado, se intentó educar a los niños en los nuevos valores, al igual que se intentaban imponer en los adultos. Esto se observa de manera especialmente puntual en la Revista Nacional de Educación, en un texto publicado en 1941, titulado "Las revistas infantiles y su poder educador" escrito por Fray Justo Pérez de Urbel. Este fraile, posterior abad del Valle de los Caídos, se interesó especialmente por el cómic, haciendo crítica de los ejemplares editados durante la República, tachando sus contenidos de "inmundicias". A sus ojos, las revistas debían gozar de una situación oficial y sustituir a los héroes de antes de la guerra (bandoleros, piratas, asaltadores de convoyes...) por "los conquistadores", etc.

Así fue, en plena guerra civil, pues la importancia educadora y propagandística de las revistas para niños fue planteada mucho antes de Fray Justo, surge la revista Chicos editada ya en el San Sebastián ocupado, con ésta competirían Flechas y Pelayos, para después unificarse en una misma revista ${ }^{12}$. En 1946 y hasta 1960, vemos a Pérez de Urbel dirigiendo la revista Clarín, publicada como revista del Movimiento; Balalín y la Ballena Alegre, serían a su vez publicadas por el Frente de Juventudes. Pero no debemos olvidarnos de las revistas para niñas, como la publicada por la Sección Femenina de Falange Española y Tradicionalista de las J.O.N.S. Ilamada Bazar ${ }^{13}$. Ningún sector de la población infantil debía quedar fuera de control.

En cuanto a los héroes contenidos en estas publicaciones, cabe señalar los ejemplos de Juan Centella y Roberto Alcázar y Pedrín (figs. 6 y 7). En todos ellos

10. Boletín Oficial del Estado (BOE), 24 de abril de 1938, nº 550, pp. 6938.

11. Acerca de este tema y de la opinión pública y su control durante la dictadura es interesante Sevillano, F., Ecos de papel. La opinión de los españoles en la época de Franco, Madrid, Biblioteca Nueva, 2000, pp. 30-40.

12. Para más información acerca de los inicios del cómic al servicio de la prensa confesional recomendamos, Martín, A., Historia del cómic español (1875-1939), Barcelona, Gustavo Gili, 1978, pp. 147-151.

13. Cirici, A., La estética..., p. 159. 
veremos, por definición una extremada agresividad natural, que nace de la fe en la justicia de los valores defendidos ${ }^{14}$. Las características físicas más peculiares de estos personajes adultos fueron el agigantamiento de la musculatura (en un intento de copia de los superhéroes americanos), aunque con una estilización autóctona que provocó un afeminamiento evidente de las figuras.

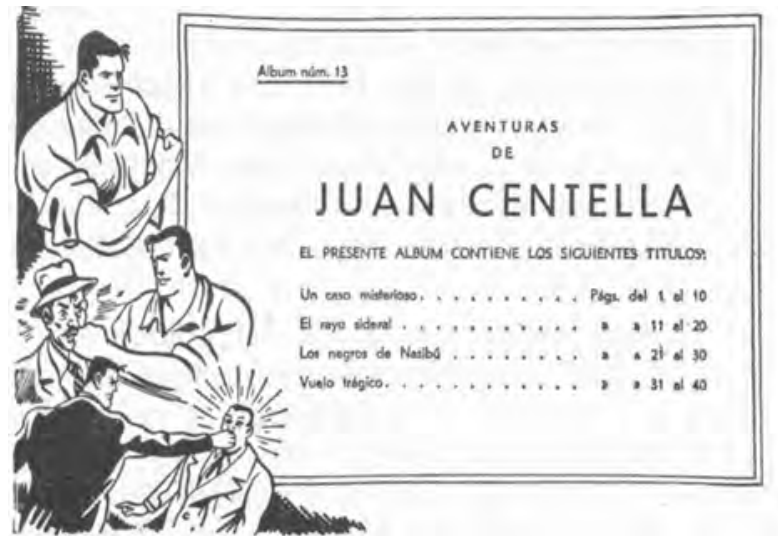

Fig. 6. Álbum de Juan Centella. Publicaciones de Hispanoamericana de Ediciones. Barcelona. Fuente: Cirici, A., La estética del franquismo, Barcelona, Gustavo Gili, 1977, p. 162.
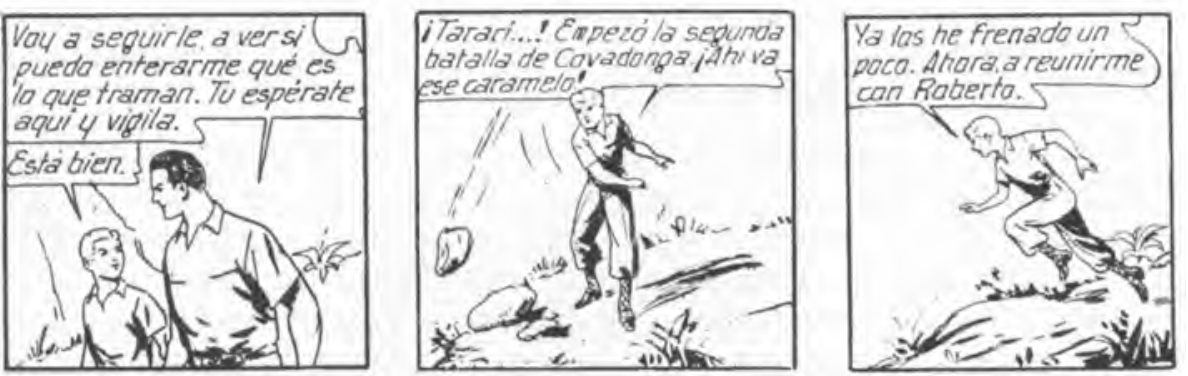

Fig. 7. Tira del cómic Roberto Alcázar y Pedrín. Editorial Valenciana de Valencia. Fuente: Cirici, A., La estética del franquismo, Barcelona, Gustavo Gili, 1977, p. 162.

14. Para mayor información leer Fandiño, R. G., "El héroe sumiso, el arquetipo masculino conformado por el franquismo desde las publicaciones juveniles al diario local", Castellani, J. P., Zapata, M. (eds.), Texte et image dans le Mondes Hispaniques et Hispano-Américains, Tours, Presses Universitaires François-Rabelais, 2007, pp. 47-55. 
Llama particularmente la atención el caso de Roberto Alcázar con un nombre de innegables connotaciones patrióticas y de una morfología facial muy similar a la de Primo de Rivera. Pedrín, su compañero infantil de aventuras será físicamente todo lo contrario de Alcázar y, por ende, de los niños españoles del momento: rubio y atlético, de tipo germánico.

En lo referente a las actividades de los héroes, no trataremos de hallar una educación en valores cívicos mediante sus acciones, sino cierto sadismo y regusto en acabar físicamente con el enemigo, que a su vez también lo es de España ("rojos", masones, judíos, etc.). Esto es fácilmente comprobable en las historietas de "Un flecha Ilamado Edmundo vence siempre a todo el mundo" con guión y dibujos del arquitecto madrileño Avelino Aróztegui, nombrado director de la revista Flecha, y cuyo personaje aparece desde su primer núme$\mathrm{ro}^{15}$. Esta constante de violencia también es observable en los cómics de temática medieval, donde las armas y luchas ante invasores de la Patria eran casi su razón de ser ${ }^{16}$.

Los personajes femeninos que aparecieron en estos cómics, fueron, al igual que los niños como Pedrín, preferentemente de tipo nórdico y de virtud intachable. Sus oficios serían "princesa", maestra o enfermera, viendo cierta evolución de la mentalidad ya a partir de los 60, al aceptar mujeres en el papel de "buenas" y que se dedicaban al periodismo o a ser azafatas como "Mary Noticias" o "Lilian azafata del aire"17. Por lo que respecta a las "malas", solían ser mujeres más o menos poderosas, ambiciosas y en busca del amor físico con el héroe, algo imperdonable en la realidad de la época y en la ficción, en muchas ocasiones reflejo de ésta.

En cuanto a las publicaciones para adultos, se puede decir que la calidad de sus imágenes fue bastante mayor que en las infantiles, aunque en cuanto a su valía como ideologizadoras estén las dos más o menos a la par, cada una adaptada al rango de edad al que se dirigía ${ }^{18}$. Pero tal vez, en este caso nos encontremos con una mayor información en cuanto a acontecimientos del momento y la relevancia dada a estos por el régimen reflejada en magníficas ilustraciones, cosa que no veremos en ninguna revista infantil, que estará más marcada por la educación en unos valores a los que apenas afectó el tiempo a lo largo de la dictadura.

15. Cirici, A., La estética..., pp. 66 y 67, MARTíN, Antonio, Historia del cómic..., p.176-179, Ramírez, J. A., "Imágenes para un pueblo (connotaciones, arquetipos y concordancias en la iconografía de la posguerra)", Bonet, A., El arte..., p. 259.

16. Herrero, H., "El cómic de ambientación medieval al servicio del franquismo", Íber. Didáctica de las Ciencias Sociales, Geografía e Historia, n 17, 1998, pp. 109-112.

17. Cirici, A., La estética..., p. 170.

18. Para más información Barrera del Barrio, C., "Políticas de información y propaganda durante el franquismo", Tusell, J., Sueiro, S., Marín, J. M., Casanova, M. (coords.), El régimen de Franco $(1939-1975) \ldots$, pp. 97-102. 
La extensión del nuevo orden social se difundió desde revistas de tipo filogermánico, filoitaliano..., quedando clara la búsqueda de la afirmación del orden social desde la imitación de otros patrones fascistas ya establecidos y, por supuesto, asentados. Entre estas revistas destacaremos Aspa y Vértice ${ }^{19}$.

La revista Aspa fue una publicación de relativa extensión en España, de influencias filogermánicas que se notan en casi todas sus ilustraciones. Su temática era netamente masculina y abordaba como temas principales el arte y la literatura. Más importancia en su difusión tuvo Vértice, magnífica publicación en sus inicios que recogía temas de actualidad reconducidos por la ideología falangista (figs. 8 y 9) ${ }^{20}$. Creada en 1937, y con excepcionales ilustradores, estos mostraron en muchos casos, el paradigma del monje-soldado que el franquismo intentó hacer de todo buen español, aunque la publicación en sí, estuvo dirigida tanto a hombres como mujeres.

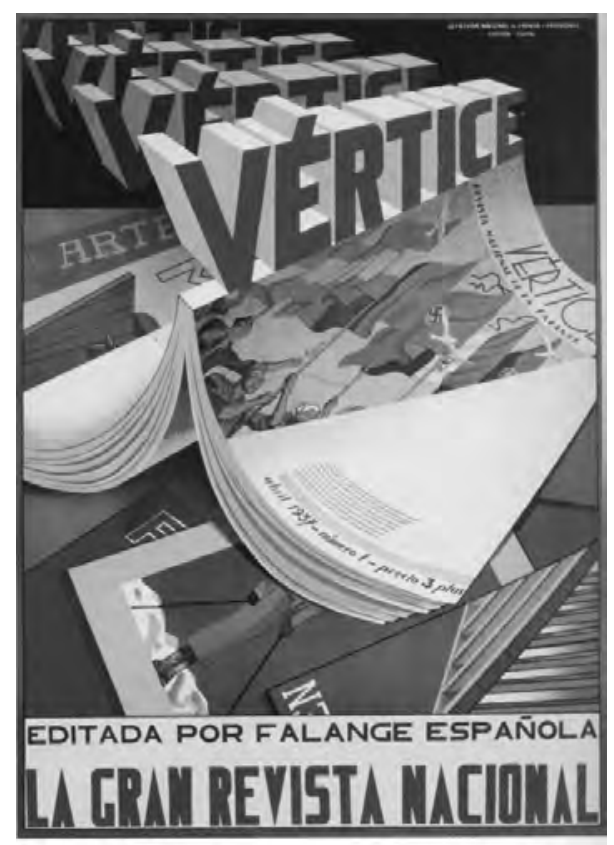

Fig. 8. Cartel anunciador del primer núm. de Vértice. Anónimo. 1937. SNP y DP. 100x69. Fuente: Carulla, J. y Carulla, A., La Guerra Civil en dos mil carteles, Vol II, Barcelona, Postermil, 1997, p. 568.

19. Ureña, G., "La pintura mural y la ilustración como panacea de la nueva sociedad y sus mitos", Bonet, A., El arte..., pp. 131 y ss.

20. Acerca de Vértice, Sánchez, J. M., Revistas ilustradas en España. Del Romanticismo a la guerra civil, Gijón, Ediciones Trea, 2008, pp. 271-272. 


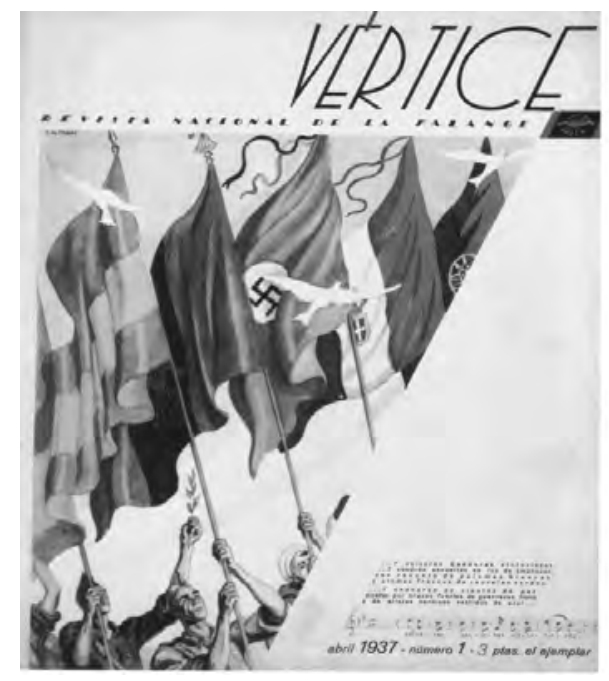

Fig. 9. Portada del núm 1 de Vértice encargada a Carlos Sáenz de Tejada. 1937. 37x28. Fuente: Carulla, J. y Carulla, A., La Guerra Civil en dos mil carteles, $\mathrm{Vol}$ II, Barcelona, Postermil, 1997, p. 568 .

Retomando el tema de los ilustradores, entre estos veremos a los ya mencionados cartelistas más algunos nombres que nos pueden resultar desconocidos, pero de larga trayectoria incluso antes de la guerra, como puede ser Acha, el cual ya había trabajado haciendo ilustraciones en Blanco y Negro, y cuya primera aparición en esta publicación puede ser datada de marzo de 1939, con su "Primavera 1900", aunque tal vez su ilustración más famosa sea "El arca de Noé guiada por Francisco Franco flota sobre el agua durante tres difíciles días" fechada en mayo de $1939^{21}$.

Uno de los principales ilustradores de Vértice fue Carlos Sáenz de Tejada, con muy buena técnica y un mejor gusto en el dibujo de una estilizada figura humana, y que nos acercará mediante sus ilustraciones a los valores falangistas de una manera delicada. Dibujante prolífico, se pueden seguir sus comienzos en la ilustración de prensa a la temprana edad de diecisiete años en el periódico El Liberal, "gran diario de izquierda", según palabras de uno de sus redactores además de familiar directo del artista como fue Antonio de Lezama ${ }^{22}$.

Otro de los destacados colaboradores de Vértice, no ya tanto en el sentido artístico del anterior sino en el campo del humor gráfico, fue Miguel Mihura bajo el seudónimo de Lilo, quien dirigió por este mismo tiempo la revista La Ametralladora, en la que contó con Tono, Edgar Neville y Álvaro de Laiglesia

21. Ureña, G., "La pintura mural...", p. 147.

22. Archivo Sáenz de Tejada, Caja 163, nº 15. 
como escritores, publicando además los chistes gráficos del propio Mihura, Tono, Teodoro Delgado, etc. ${ }^{23}$

No obstante, y pese al valor de estas ilustraciones como documentos para el análisis de la Historia, poco o nada sirven para el estudio de la Historia del Arte, si no es para decir que no se creó nada nuevo, sino que apoyados en el gusto burgués ya existente, los artistas se dedicaron a una expansión de ideas principalmente filogermánicas. Sólo a partir del segundo quinquenio de los años 40 veremos obras, que si bien no pueden ser calificadas de vanguardistas, exaltan al régimen desde una perspectiva renovada, probablemente debido al fracaso de las otras dictaduras europeas ${ }^{24}$.

\section{Retratística del Jefe del Estado y otras personalidades}

Hay que tratar, obligadamente, la profusión de retratos que hubo durante la permanencia del régimen dictatorial de sus más destacadas personalidades. Pues si queremos analizar cómo se puede usar la imagen para el estudio de la Historia, esta será una fuente útil y abundante, con vocación de permanencia, a diferencia de la cartelística e incluso de las publicaciones.

Durante la primera época del franquismo, numerosos fueron los retratos exentos o sobre objetos cotidianos, como por ejemplo, relojes y lámparas de las personas conformantes del "Alzamiento", sobre todo de Francisco Franco y de José Antonio Primo de Rivera. Esta especie de fiebre de culto a los líderes pronto habría de ser legislada para imponer cierta moderación a través de la censura en el uso de las efigies, sobre todo, y dado el caso, del "Caudillo" y de "El Ausente". Para lo cual, se dictó la Orden del 24 de abril de 1938, la ya citada Ley Serrano Súñer, que encomendaba al Servicio Nacional de Prensa y Propaganda la concesión de la autorización de "la producción comercial y circulación de libros, folletos y toda clase de impresos y grabados, tanto españoles como extranjeros" con ciertas efigies.

Las principales modalidades de la iconografía de Franco fueron la de a pie, la militar o a caballo, aunque estas últimas no son tan comunes a la representación gráfica. Abundaron más los bustos y las cabezas que los retratos de cuerpo entero, siendo estos más numerosos en los óleos del dictador (figs. 10 y 11). Su rostro siempre es severo y serio como corresponde a un militar triunfador en sus diferentes poses (Franco Jefe de Estado, Franco falangista y requeté, Franco cruzado, Franco cazador...). Nos seguimos alejando así de las teorías de

23. Martín, A., Historia del cómic..., p. 209.

24. Para ampliar información consultar Belmonte, F., "Los mecanismos de difusión del discurso oficial en la prensa cultural del primer franquismo", Delgado, J. M. (coord.), Propaganda y medios de comunicación en el primer franquismo (1936-1959), Logroño, Universidad de La Rioja, 2006, pp. 29-50. 
Giménez Caballero... Todos estos retratos pueden servir para el estudio comparativo de la imaginería y la mentalidad autóctona de nuestro régimen con el italiano y alemán.

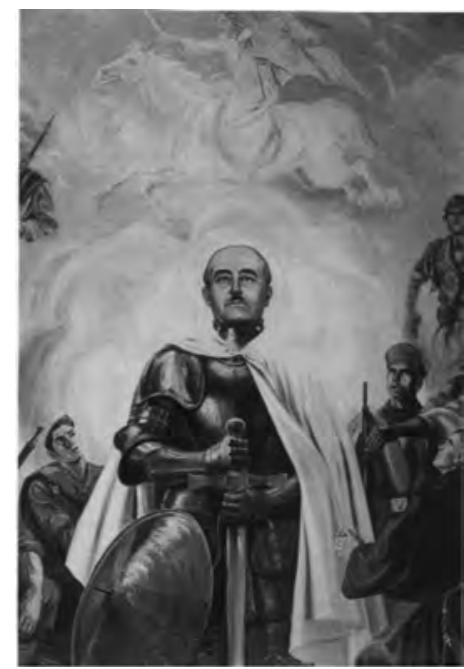

Fig. 10. Alegoría de Franco y la Cruzada. Pintura mural de Reque Meruvia. Archivo Histórico Militar en Madrid. Fuente: www.terra.es/personal/waffen31/franco.htm (última consulta: 11 de mayo de 2011).

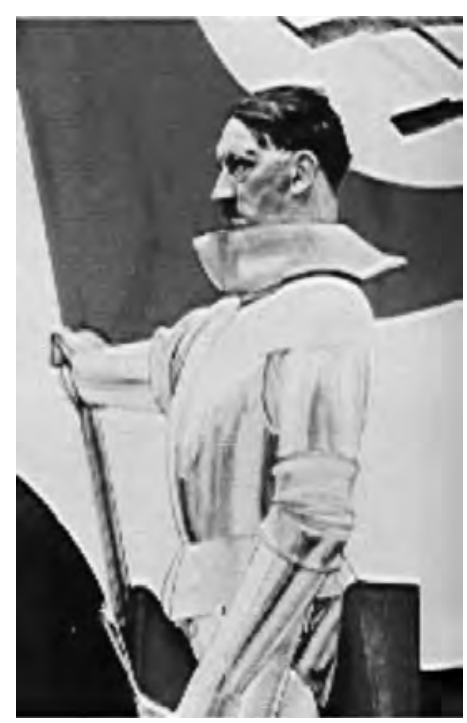

Fig. 11. Hitler, también con coraza, como portaestandarte de la Nueva Alemania. H. Lanzinger. Fuente: www. recollectionbooks.com/ siml/images/Images (última consulta: 11 de mayo de 2011).

La ideología franquista, no se sabe hasta qué punto "pacata", como dice Llorente en su libro, o prudente, hizo del todo imposible la representación de un Franco desnudo o en actitud atlética y a pecho descubierto, como sí que 
encontramos a Mussolini ${ }^{25}$ (fig. 12). El caso es que la idealización de la imagen de nuestro "Caudillo" es algo comprobable, pues se rejuvenecía su rostro y se estilizaba su figura. En definitiva, se le daba un porte que no tenía, propio de los retratos barrocos.

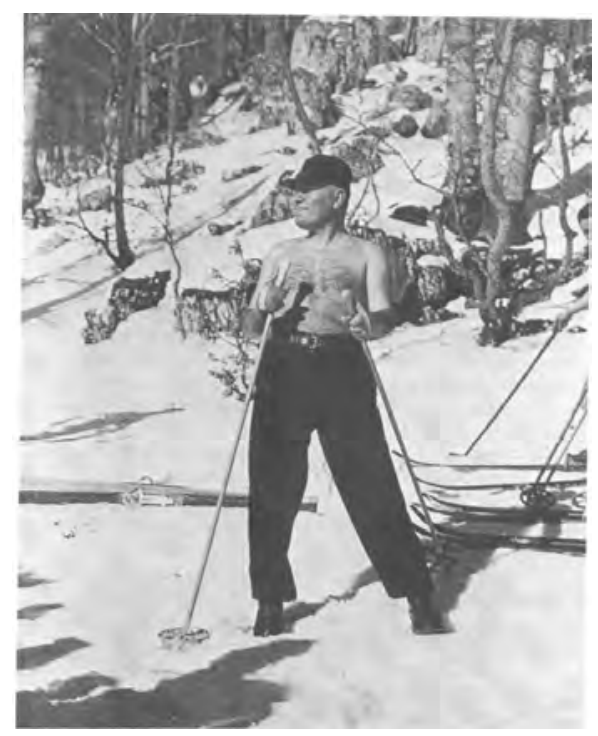

Fig. 12. Imagen de Mussolini acreditando la fortaleza del Duce. Fuente: FalascaZamponi, S., Fascist Spectacle. The aesthetics of power in Mussolini's Italy, Los Ángeles, University of California Press, 1997, p. 73.

Los principales retratistas de Franco fueron numerosísimos destacando entre ellos Zuloaga, Enrique Segura, Aladrén, Ismael Blat, Benlliure, Capuz, M. de la Huerta, Julio Moisés, V. Navarro, Pons Arnau, Fleitas, Benedito, Cárdenas, Vázquez Díaz, Laviada, Torre Isunza, Aguiar, Álvarez de Sotomayor, Marceliano Santamaría, Morales, Juan Cristóbal, Ignacio Pinazo, Víctor Moya, Ramón Mateu, Cossío... Pero sólo privilegiados como Zuloaga o Benlliure trabajaron con modelo vivo ${ }^{26}$.

Tras el dictador, la personalidad más retratada del régimen y debido al uso que se hizo de Falange, fue José Antonio Primo de Rivera, aunque en bastante menor proporción que Franco tanto en número como en calidad. Los más destacados retratistas del fundador de la Falange fueron Adsuara, Aladrén, Capuz, Cárdenas Guerra, F. Culebras, Dunyach, Martín Bautista, Laviada, Lucarini,

25. Llorente, Á., Arte e ideología en el franquismo (1936-1951), p. 207, Editorial Visor, Madrid, 1995.

26. Llorente, Á., Arte e ideología..., p. 203. 
Monteverde, R. Navarro, A. G. Zaragoza, M. del Pino, J. Higueras, Segura, R. Zaragoza, Vázquez Díaz y L. Mosquera ${ }^{27}$.

El régimen totalitario español, por lo menos en sus primeros tiempos llevó a cabo la utilización de la ideología falangista, pues era una dictadura militar carente de programa político. Siendo así, éste siempre fue representado sereno, embellecido y como una persona de carácter en sus diferentes cabezas, bustos y torsos. Como consecuencia lógica de este uso ideológico, siempre que José Antonio aparezca en busto y torso, presentará una postura monolítica de brazos cruzados, con apariencia estática (fig. 13). Pero poco a poco, el ideólogo de Falange irá siendo menos representado, pues como dijo en su momento Agustín de Foxá para ilustrar la molestia que sentía Franco por la exaltación de José Antonio después de muerto: "Es como si un hombre se casa con una viuda y ésta se pasa el día hablando de su primer marido" ${ }^{28}$.

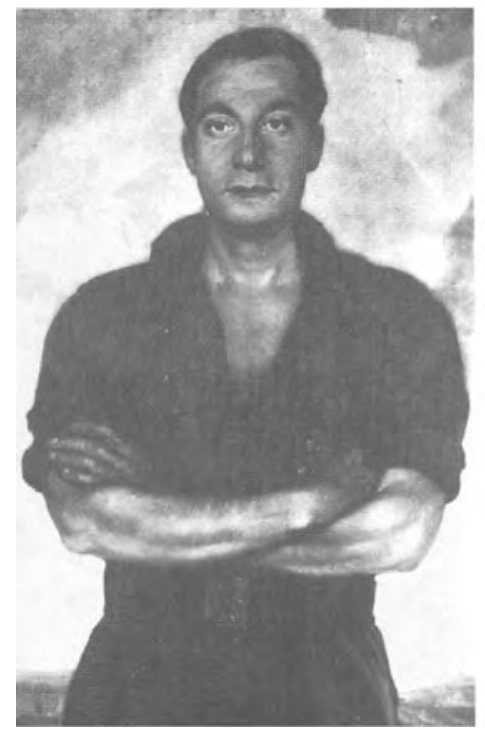

Fig. 13. Imagen

"monolítica" de José

Antonio retratado por Luis

Mosquera. Fuente: Llorente, Á., Arte e ideología en el franquismo (1936-1951), Madrid, Visor, 1995, p. 211.

Después de los dos pilares del régimen, los militares que contribuyeron al "Alzamiento" fueron las personalidades más representadas y, entre estos, los que mayor número de retratos tuvieron fueron: Mola, Millán Astray (el Glorioso Mutilado), Varela, Moscardó, Orgaz, Muñoz Monasterio, Jordana, etc. Siendo

27. Llorente, Á., Arte e ideología..., pp. 210-211.

28. Carulla, J. y Carulla, A., La Guerra... p. 528. 
famosos los retratos fotográficos encargados por el Servicio Nacional de Propaganda en torno a 1940 y de unas dimensiones de 38 x 28, haciéndose especialmente famosa la fotografía que representa a Queipo de Llano en su faceta de radioaficionado al frente de Unión Radio S.A. ${ }^{29}$ (fig. 14).

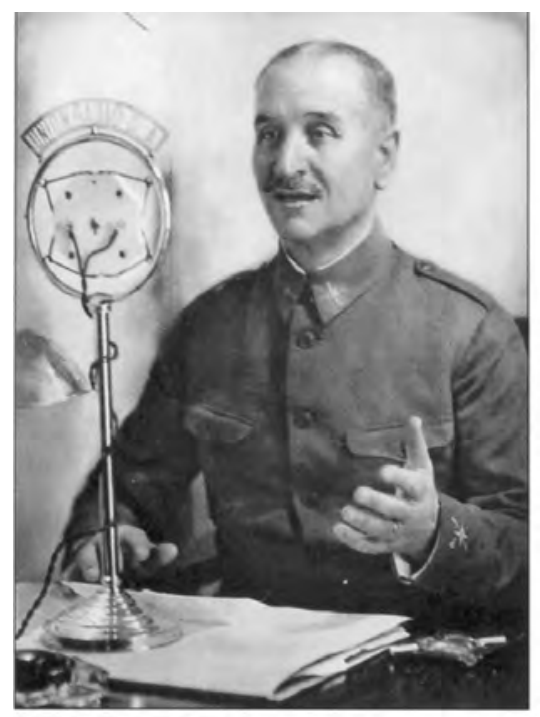

Fig. 14. Fotografía desde la oficialidad de Queipo de Llano. Fuente: Carulla, J. y Carulla, A., La Guerra Civil en dos mil carteles, Vol II, Barcelona, Postermil, 1997, p. 548.

En cuanto a los civiles más representados nos encontramos con: Onésimo Redondo y Pilar Primo de Rivera (hermana de José Antonio y fundadora de la Sección Femenina de Falange). Pero en ningún momento será comparable el número de retratos de personajes civiles con los de militares como podemos comprobar.

\section{Cine y Noticiario Documental (NO-DO)}

Se dice que toda filmación está compuesta de imágenes en movimiento donde el grafismo entra como un componente más, tal es así, y debido a la importancia de las filmaciones como medio de masas y reflejo de la ideología dominante, que este trabajo hubiese resultado incompleto de no dedicar un epígrafe al análisis del cine producido durante el franquismo, y al famoso Noticiario Documental más conocido por NO-DO cuyos contenidos son Historia en movimiento.

29. Carulla, J. y Carulla, A., La Guerra... pp. 548-549. 


\subsection{El cine}

El periodo cinematográfico más interesante del franquismo es el que se hizo durante el tiempo que duró la autarquía, ya que representó los valores patrios, tal vez de formas no muy variadas, pues las cintas si por algo destacan es por su falta de originalidad, pero lo hizo de una manera inconfundible y con unas características que se observan en todos los ámbitos artísticos: historicismo, dramas patrios, sainetes o folclorismos y grandes dosis de cultura religiosa (por algo se designó a la ideología del régimen como nacionalcatólica en sus primeros tiempos). La gran profusión de películas que vemos en aquellos momentos, nos puede resultar paradójica dado el escenario de desolación y pobreza en España, pero no debe extrañarnos, ya que el cine fue un gran orientador de los hábitos de vida de los españoles, y como tal lo tuvieron desde un primer momento en el nuevo Estado, por lo que el Ministerio de Industria y de Comercio se encargó de controlar bien las películas producidas creando, en cuanto la economía se recuperó un poco, la categoría de Película de Interés $\mathrm{Nacional}^{30}$, y siendo ayudados económica y técnicamente, en un primer momento, por Alemania e Italia ${ }^{31}$.

Lo cierto es que al principio de la contienda civil, salvo en la zona republicana, más dedicada a hacer documentales informativos que películas; en los territorios que iban siendo ocupados por los nacionales apenas se ve actividad cinematográfica, puesto que los medios eran escasos, pero aún así sí que se dieron estrenos de películas rodadas aceleradamente para imponer nuevas ideas y hacer olvidar las adquiridas, ya que a partir de octubre de 1937 fue obligatoria en las salas de cine la ejecución del himno nacional en sus dieciséis primeros compases, mientras que en la pantalla se proyectaba un retrato de Franco que los espectadores tenían que saludar al modo fascista permaneciendo de pie mientras durase el himno, durando esta imposición hasta $1940^{32}$.

Pasado este paréntesis en la producción cinematográfica, dos fueron las grandes productoras españolas en un principio: CIFESA y SUEVIA FILMS. Las dos trataron de imitar a las producciones alemanas e italianas, e incluso CIFESA, la más internacional de ambas, Ilegaría a rodar películas en los estudios de la UFA alemanes, pues Goebbels anteriormente ya había intentado crear una productora berlinesa de nombre Hispano-Film-Produktion que nunca vio a la luz ${ }^{33}$. CIFESA

30. BOE, 23 de junio de 1944, $\mathrm{n}^{\circ} 175,4926$.

31. López, Ma . S., "El cine como elemento educativo en Valladolid (1936-1951)", Company, A., Pons, J., Serra, S. (coords. y eds.), La comunicació audiovisual en la història, Vol. II, Palma de Mallorca, Universitat de les Illes Balears, 2003, pp. 773-774.

32. CRUSELLS, Magí, La Guerra Civil española: cine y propaganda, Barcelona, Ariel, 2000, pp 74-75.

33. SCHULZE, Ingrid, "La fe de Goebbels en la propaganda fílmica: el ejemplo de Kolberg", Company, A., Pons, J., Serra, S. (coords. y eds.), La comunicació..., pp. 1029-1031. 
también rodaría fuera de España, en los estudios de Cinecittá de la Italia mussoliniana ${ }^{34}$.

La primera de estas productoras fue fundada por el valenciano Vicente Casanovas en 1932, y en pocos años se convirtió en la abanderada del régimen franquista del cual recibió todo tipo de incentivos, beneficios y honores, por ejemplo, en 1940, la productora, totalmente adaptada a los gustos burgueses del momento, recibe la mención de honor del Sindicato Nacional del Espectáculo, lo que se tradujo en compras de títulos por valor de cuarenta y cinco millones de pesetas, cuando en realidad la empresa sólo había puesto en circulación doce millones ${ }^{35}$.

Pero este trato diferencial no es de extrañar si miramos sus actividades, puestas al entero servicio de la dictadura, y por lo tanto, de Franco, quien haría de guionista de una de las películas más famosas de esa época Raza bajo el pseudónimo de Jaime de Andrade y que fue dirigida por Sáenz de Heredia, uno de los directores junto a Benito Perojo, Florián Rey y Edgar Neville, más ensalzado. Como nota curiosa a esta película hay que destacar que a pesar de ser realizada por el cuñado de José Antonio Primo de Rivera, no se menciona en ningún momento a la Falange, aunque sí profusamente al "Caudillo". Esto viene a revelarnos la atención mostrada por las películas estrenadas en las salas españolas, observando celosamente sus contenidos por medio de la censura, para cuyo desempeño se creó la Subcomisión Reguladora de la Cinematografía ${ }^{36}$.

Llama la atención, si vemos unas cuantas películas, para contradecir las ideas preconcebidas que pudiésemos tener de ellas, que en casi ninguna, más que las dedicadas a las hazañas bélicas como por ejemplo $A$ mi la legión, Sin novedad en El Alcázar, o La fiel infantería, encontramos águilas de San Juan u otros símbolos del patriotismo del momento (fig. 15). Incluso en algunas como el Frente de Madrid, dirigida por Edgar Neville, se intentaron introducir elementos de reconciliación nacional, pues esta película acababa con un abrazo entre un soldado nacional y otro republicano, ambos heridos, aunque este final primigenio duró poco, ya que la censura obligó a su eliminación ${ }^{37}$.

34. TAIBO, P. I., Un cine para un imperio, Madrid, OBERON, 2002, p. 15.

35. Font, D., "El cine español durante la autarquía", en Bonet, A. (coord.), El arte del franquismo, Madrid, Cátedra, 1981, p. 297.

36. BOE, 21 de octubre de 1939, no 294, pp. 5895-5896.

37. Taibo, P. I., Un cine..., p. 28. 


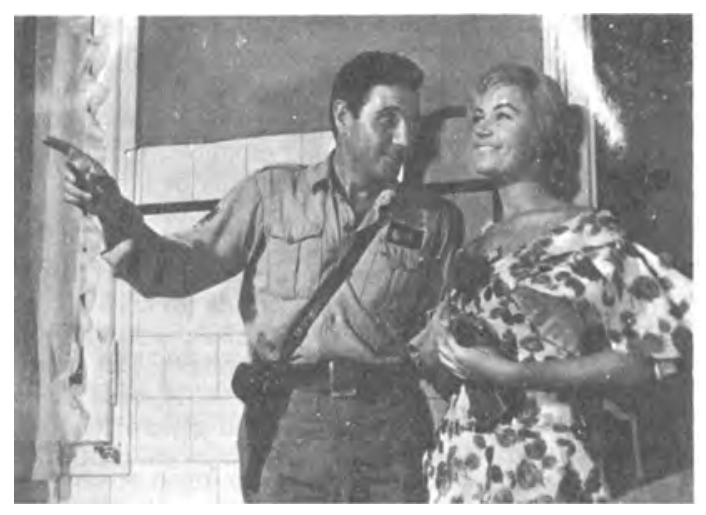

Fig. 15. La fiel infantería (1959), dirigida por Pedro Lazaga. Película en la que se repite hasta la saciedad el nombre de Franco. Fuente: Bonet, A. (coord.), El arte del franquismo, Madrid, Cátedra, 1981, p. 298.

Pero una vez pasados los primeros tiempos de asentamiento de la dictadura, poco tendrá que hacer ya CIFESA, pues los gustos burgueses han cambiado y se necesita una renovación de estilos que no vendrá nunca, ya que por falta de capital, desaparecerá (fig. 16). Ahora el cine busca un cierto cosmopolitismo burgués y nuevos argumentos, creándose con el capital emanado de este sector de la sociedad SUEVIA FILMS a finales de la década de los 40, y que será la productora estrella hasta finales del periodo autárquico.

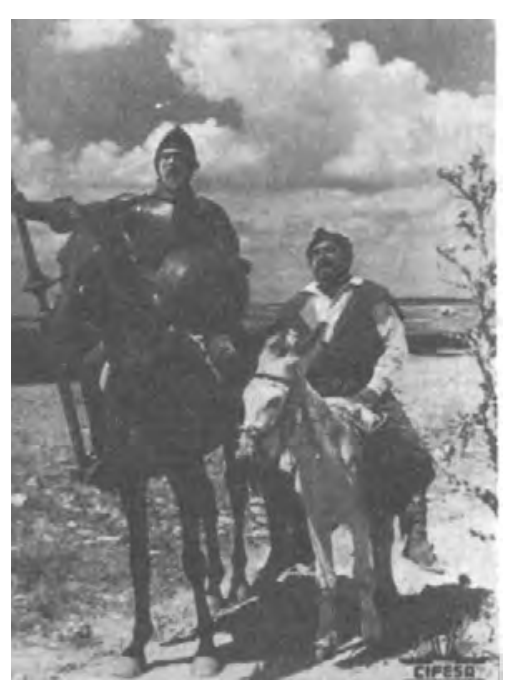

Fig. 16 Don Quijote de la Mancha (1947), dirigida por Rafael Gil y producida por CIFESA. Fuente: Bonet, A. (coord.), El arte del franquismo, Madrid, Cátedra, Madrid 1981, p. 309. 
A partir de la creación de esta productora veremos una especie de punto y aparte entre tanto militarismo y folclorismo (fig. 17). En una España en que parece que la economía se recupera, aunque levemente, las clases medias quieren otro tipo de cine que vendrá con películas como Mariona Rebull dirigida por Sáenz de Heredia y otros productos que podríamos designar como caligráficos, al igual que lo hace Font, pues sus argumentos vienen directamente de prestigiosos libros y, en concreto, de la novela decimonónica más reaccionaria ${ }^{38}$.

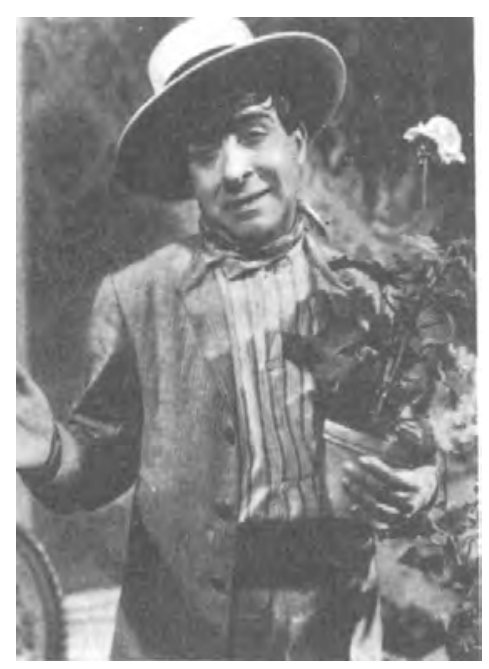

Fig. 17 Suspiros de España (1938), dirigida por Benito Perojo. Tópica imagen del gitano y del folclorismo español más recalcitrante. Fuente: Bonet, A. (coord.), El arte del franquismo, Madrid, Cátedra, 1981, p. 309.

No obstante, pese a la ligera apertura argumental que supuso SUEVIA FILMS, será a partir de 1947, cuando empiece a aparecer un cine con verdaderas miras al exterior y con ciertos criterios de mercado. Ignacio F. Iquino desde su empresa familiar Emisora Films, fundada en Barcelona en 1943, dará paso a nuevos directores como Bardem y Berlanga, los cuales nos darán las obras cumbre de la cinematografía de esos momentos, tanto en calidad de rodaje con medios precarios, como en la historia relatada, reflejo muchas veces amargo de la realidad más desdichada de la sociedad española, lo que en numerosas ocasiones resultó más que incómodo para la censura y para los dos directores a causa de ésta ${ }^{39}$.

En conclusión, no se puede tildar a la cinematografía de la autarquía y a la posterior como netamente fascistas, pues no fue así y pocas veces se rodaron

38. Font, D., "El cine español...", pp. 310 y ss.

39. Font, D., "El cine español...", p. 312. 
películas directamente encargadas por la Falange. Tampoco se trató de aplicar con femasiada frecuencia lecciones religiosas a través de la pantalla, pues había otros medios para hacerlo, sino que se intentó alimentar el imaginario del espectador y organizar esquemas de comportamiento. Hubo, en el cine, todo un trabajo consciente de guión y dirección para tocar la cotidianeidad y que, por vía emocional, se consiguiese crear un único patrón de comportamiento colectivo ${ }^{40}$.

\subsection{EI NO-DO}

Si en el cine hemos visto el trasfondo de toda una ideología, más claramente la veremos en unas proyecciones periódicas dedicadas al ensalzamiento de la figura de Franco y las bondades del régimen como es este Noticiario Documental, creado por Orden de la Vicesecretaría de Educación Popular del 17 de diciembre de 1942, a raíz de los sucesos ocurridos en Begoña el 15 de agosto de ese mismo año, con el atentado por parte de unos carlistas al general Varela cuando se hallaba en la basílica de Begoña y que causó multitud de informaciones descontroladas, sobre todo en el extranjero, lo que obligó a Gabriel Arias Salgado, vicesecretario de Educación Popular, a contactar con los responsables del noticiario alemán Actualidades UFA, y del norteamericano FOX Movietone, para que le fuese remitido todo el material rodado sobre el hecho que pudiese existir, a fin de poder fiscalizar esa información ${ }^{41}$. Dadas las circunstancias de su nacimiento, la declaración de principios de este noticiario no deja lugar a dudas: La necesidad de disponer de un eficaz instrumento cinematográfico propio que pueda ser destinado en primer lugar a difundir la obra del Estado en el amplio orden de la reconstrucción nacional y, en segundo lugar, mantener con impulso propio la directriz adecuada a las informaciones cinematográficas nacionales, queda plasmada en la creación del noticiario $\mathrm{NO}-\mathrm{DO}^{42}$ (fig.18).

40. Acerca del tema ver Díez, E., "El montaje del Franquismo: la política cinematográfica de las fuerzas sublevadas", Cuadernos de Historia Contemporánea, n² 23, Madrid, Universidad Complutense de Madrid, 2001, pp. 141-157 y Martín de la Guardia, R., "Los medios de comunicación social como formas de persuasión durante el primer franquismo", Delgado, J. M., Propaganda y medios de comunicación en el primer franquismo..., pp. 25-27. En cuanto al papel de la mujer en el cine leer Labanyi, J., "Historia y mujer en el cine del primer franquismo", Secuencias. Revista de Historia del cine, $\mathrm{n}^{\circ}$ 15, Madrid, Instituto Universitario de Ciencias de la Educación, Universidad Autónoma de Madrid, 2002, pp. 42-59.

41. Rodríguez, A., "NO-DO: el origen. Razones que motivaron la creación de la imagen oficial del régimen", García, J. A., Gutiérrez, J. F., Sánchez, I. (eds.), La comunicación social durante el franquismo, Málaga, Centro de Ediciones de la Diputación Provincial de Málaga, 2002, p. 267.

42. Font, D., "El cine español...", p. 300. 


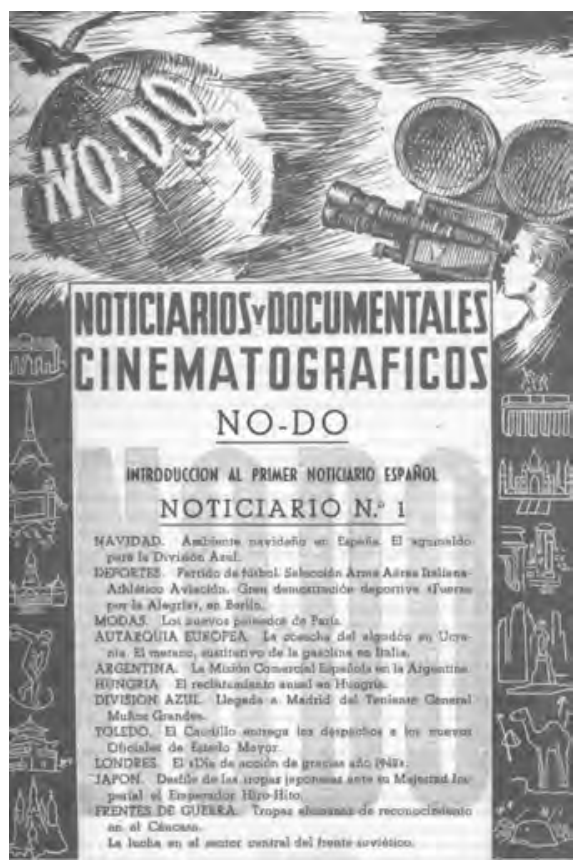

Fig. 18. Programa de la edición número 1 del NO-DO, el 4 de enero de 1943. Fuente: Tranche, $R$. R. Y Sánchez-Biosca, V., NO-DO. El tiempo y la memoria, Madrid, Cátedra/ Filmoteca Española, 2000, p. 5.

En cuanto al primer objetivo, ciertamente se cumplió, pues en los primeros tiempos del noticiario habrá gran aproximación a los argumentos de la UFA en Alemania y del "Cinegiornale Luce" en Italia. No había nada nuevo bajo el sol. Para un intento de establecimiento de un nuevo Estado nada hubo en realidad tan legitimador como los éxitos expuestos en los documentales de las potencias europeas del Eje, sobre todo los alemanes, cuyas imágenes eran enviadas para su uso exclusivo en España siguiendo el convenio firmado el 20 de noviembre de 1942 entre Fritz Tietz, que se ocupaba de la Sección Extranjera de Actualidades UFA en España, y Joaquín Soriano, director del NO-DO, por el que además de estas imágenes, Alemania facilitaría para el rodaje del noticiario español material de rodaje y técnico ${ }^{43}$.

Lamentablemente para los guionistas que habían encontrado en los éxitos fascistas vecinos un filón casi inagotable, el mismo año de creación del NODO, la Segunda Guerra Mundial empieza a dar la vuelta en favor de las Potencias Aliadas, lo cual provocará que el noticiario se aleje cada vez más de las similitudes con las producciones extranjeras y adopte unas características propias. Hay que decir que en 1939 ya se estaban proyectando los documentales

43. Rodríguez, A., "NO-DO: el origen. Razones...", p.270. 
UFA y el "Cinegiornale Luce" en España, así como el más directo antecesor del NO-DO, que fue el Noticiario Español, creado en 1938 desde el Departamento Nacional de Cinematografía, y que se diferencia ideológicamente de su predecesor en que, mientras que éste, en tiempos de guerra pretendía construir una mentalidad, el segundo, en tiempos de paz, procuró afianzarla. Más todo llega a su fin, y con el término de la Guerra Mundial, la derrota de las potencias fascistas y la delicada situación de aislamiento internacional de España, harán que la falta de película Agfa nazi se sustituya por la Kodak, y los noticiarios extranjeros por los de la Paramount News y la Fox Movietone News. Al amparo de este nuevo rumbo, los argumentos del NO-DO se transformarán en una peculiar presentación de una España avanzada, incluso dentro de su subdesarrollo, con multitud de inauguraciones de pantanos y apertura de nuevas fábricas, procurando dirigir también una mirada al exterior desde el filtro del Estado, que cambió su admiración ante el potencial militar alemán por el estadounidense ${ }^{44}$.

Por lo que respecta al segundo objetivo, nada más fácil, pues no olvidemos que la prensa y la propaganda estaban totalmente fiscalizadas con la Ley Serrano Súñer desde 1938 y, ninguna información, podía ser ajena al Estado sin caer en la ilegalidad. La proyección del NO-DO, además, era obligatoria en todos los locales de cine del territorio español, y aunque en cierta manera esto creó rechazo en parte de la población, no hay duda de que cumplió con el envío de fuertes cargas ideológicas a ésta, explicándose su efectividad por medio de la exclusividad, ya que no había manera alguna de contrastar las noticias mostradas con otros medios de comunicación libres de censura ${ }^{45}$. Además, este noticiero, de una duración media de entre 10 y 11 minutos, se llegó a hacer en dos versiones desde 1943, la A y la B cuyas diferencias se supone que estaban en los contenidos, aunque muchas veces sólo se encontraron en el orden de estos $^{46}$.

Respecto al tratamiento de las figuras del régimen, el noticiario hizo una buena labor, sobre todo benévola con la persona de Francisco Franco, pues parece ser que el dictador se sentía más seguro en manos de sus retratistas que en las de los cámaras que lo rodaban, dada su voz atiplada y corta estatura, algo que le acomplejaría desde la adolescencia. Precisamente por esto, Franco siempre aparecerá difuso en los documentales, muchas veces rodeado de grandes multitudes que lo difuminan, o en lo alto de un podio para dirigirse a la masa. Pocas veces hablará, sino que será la voz en off de quien relata las imágenes quien lo sustituya en su discurso, haciendo un breve resumen de lo que está aconteciendo.

44. Rodríguez, S., El NO-DO. Catecismo social de una época, Madrid, Editorial Complutense, 1999, p. 210.

45. Rodríguez, S., El NO-DO. Catecismo..., p. 57.

46. Tranche, R. R. y Sánchez-Biosca, V., No-Do. El tiempo y la memoria, Madrid, Cátedra/ Filmoteca Española, 2000, pp. 105 y 161. 
Realmente, ésta fue una buena labor dirigida al ensalzamiento no sólo de la construcción de un nuevo orden, sino del personaje que lo dirigía, aprendida directamente de quienes habían sido aliados extranjeros durante la Guerra Civil.

Finalizando, ningún ámbito de la vida del español medio escapó del dirigismo del Estado. Llámese engaño o manipulación (los dos términos pueden resultar apropiados), incluso en los lugares de ocio como pudo ser el cine, entretenimiento de masas donde los haya en unos años de gran carestía, la gente se encontró no sólo con unas películas de ínfima calidad dignas del lema romano "Panem et circenses", sino que previamente debían ver obligados una información que estaba llena de triunfalismo donde sólo había miseria (fig. 19).

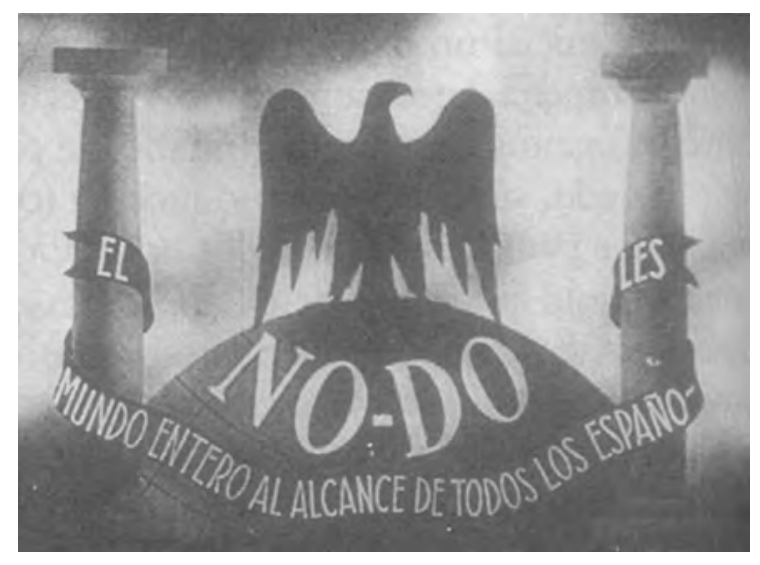

Fig. 19. Imagen de cierre del Noticiero Documental. Fuente: Tranche, R. R. Y Sánchez-Biosca, V., NO-DO. El tiempo y la memoria, Madrid, Cátedra/Filmoteca Española, 2000, p. 98.

\section{Conclusiones}

Llegados a este punto, ya estamos habilitados para emitir unas conclusiones acerca de las imágenes gráficas del franquismo y que éstas puedan resultar coherentes, pues hemos podido ver las principales manifestaciones del imaginario de la época representado por la cartelística, las publicaciones, la retratística del Jefe del Estado y otras personalidades, así como el cine y el Noticiario Documental.

El principal punto sobre el que podría recaer nuestra atención, y aunque pueda resultar repetitivo, es que ninguna esfera de la vida de los españoles quedó fuera de las marcadas directrices ideológicas del régimen franquista y, es por ello, por lo que cobran su importancia la iconografía del momento, puesto 
que tendrá un valor inestimable a la hora del estudio de este periodo de la historia de España y su influencia en la mentalidad de los españoles ${ }^{47}$.

Se puede aseverar que todas las imágenes se ocuparon de abarcar un sector de la población, cuando no varios. Por ejemplo, los carteles, tomaron a todos los sectores de la población como espectadores, y debido a la expresividad de las imágenes contenidas en estos, no era necesario saber leer o escribir para captar el mensaje emotivo que directamente enviaban a las retinas.

En el caso de las publicaciones gráficas, sí que se ocuparon de diferentes sectores poblacionales, pero sobre todo de aquél que sabía leer y escribir. Lo que no quiere decir que debido a la vehemencia de las ilustraciones no emitieran mensajes inteligibles por si mismas. Daba igual gente adulta (hombres y mujeres) que joven (niños, niñas y adolescentes en general), a todos se les dosificó la ideología imperante a través de las páginas de las revistas y cómics. A unos para convencer y a otros para educar.

Por lo que respecta a la retratística, la idea de sus patrocinadores fue la de llegar a todo el mundo a través de su imposición en los lugares públicos, lo cual no quita que estos retratos también fuesen objeto de venta a domicilio. Desde luego, quien los observara no era necesario que fuese letrado, pues todo se decía (o hacía entender) con la pose de las personalidades del régimen en la fotografía o la pintura, dando además una idea de imperium y dignidad que se intentaba que fuera la que subyaciese en el inconsciente colectivo. Precisamente por esto, se hizo tan importante la legislación sobre la utilización de imágenes de Francisco Franco y José Antonio Primo de Rivera.

En cuanto al NO-DO, imagen en movimiento y con sonido unida a un indudable grafismo en su estilo, fue el noticiario del régimen de visión obligatoria en todos los cines de España. Su misión fue la de unificar la información para evitar desmanes periodísticos y hacérsela llegar a todos los sectores poblacionales, sin distinciones. En él se dio una imagen ideal de lo que era la Nueva España, bastante poco creíble cuando se abandonaba la sala de proyección y se observaban con ojos propios las desgracias de posguerra.

Por estas razones, debe constar la valía de las imágenes gráficas del franquismo como documento histórico y como conformadoras de la opinión pública, sobre todo en sus primeros tiempos, pues nos habilitan para poder apreciar bien todos los detalles ideológicos reflejados por un estilo y unas formas que querían transmitirse a la población. Pero tendrán que ser estudiadas siempre con ojos críticos, pues a partir de aquí es de suponer que ha quedado patente que, la imagen, suele está al servicio de las clases dominantes y más en tiempos de dictadura.

47. Resulta interesante la consulta a este respecto de Chuliá, E., "Opinión pública, democracia y dictadura", Anales de la Cátedra Francisco Suárez, n 34, Granada, Universidad de Granada, 2000, pp. 45-60. 


\section{Bibliografía y Fuentes}

BONET, A. (coord.), El arte del franquismo, Madrid, Cátedra, 1981.

BOZAL, V., Summa Artis. Pintura y escultura españolas del siglo XX (1900-1939), Vol. XXXVI, Madrid, Espasa-Calpe, 1992.

BURKE, P., Visto y no visto. El uso de la imagen como documento histórico, Barcelona, Crítica, 2001.

CARULLA, J. y C., A., La Guerra Civil en dos mil carteles, Vol II, Barcelona, Postermil, 1997.

CHULIÁ, E., "Opinión pública, democracia y dictadura", Anales de la Cátedra Francisco Suárez, n 34, Granada, Universidad de Granada, 2000, pp. 45-60.

CIRICI, A., La estética del franquismo, Barcelona, Gustavo Gili, 1977.

COMPANY, A., Pons, J. y Serra, S. (eds. y coords.), La comunicació audiovisual en la història, Vol. II, Palma de Mallorca, Universitat de les Illes Balears, 2003.

CRUSELLS, M., LA Guerra Civil española: cine y propaganda, Barcelona, Ariel, 2000.

DELGADO, J. M. (coord.), Propaganda y medios de comunicación en el primer franquismo (1936-1959), Logroño, Universidad de la Rioja, 2006.

DÍEZ, E., "El montaje del Franquismo: la política cinematográfica de las fuerzas sublevadas", Cuadernos de Historia Contemporánea, n 23, Madrid, Universidad Complutense de Madrid, 2001, pp. 141-157.

GARCÍA, J. A., Gutiérrez, J. F., Sánchez, I. (eds.), La comunicación social durante el franquismo, Málaga, Centro de Ediciones de la Diputación Provincial de Málaga, 2002.

LABANYI, J., "Historia y mujer en el cine del primer franquismo", Secuencias. Revista de Historia del cine, $\mathrm{n}^{\circ}$ 15, Madrid, Instituto Universitario de Ciencias de la Educación, Universidad Autónoma de Madrid, 2002, pp. 42-59.

LLORENTE, Á., Arte e ideología en el franquismo (1936-1951), Madrid, Visor, 1995.

MARTÍN, A., Historia del cómic español (1875-1939), Barcelona, Gustavo Gili, 1978.

RAMÍREZ, J. A., Medios de masas e historia del arte, Barcelona, Cátedra, 1992.

RODRÍGUEZ, S., El NO-DO. Catecismo social de una época, Madrid, Editorial Complutense, 1999.

SÁNCHEZ, J. M., Revistas ilustradas en España. Del Romanticismo a la guerra civil, Gijón, Ediciones Trea, 2008.

SANTONJA, G., De un ayer no tan lejano. Cultura y propaganda en la España de Franco durante la guerra y los primeros años del Nuevo Estado, Madrid, NOESIS, 1996. 
SEVILLANO, F., Ecos de papel. La opinión de los españoles en la época de Franco, Madrid, Biblioteca Nueva, 2000.

TAIBO, Paco Ignacio, Un cine para un imperio, Madrid, OBERON, 2002.

TRANCHE, R. R. y Sánchez-Biosca, V., NO-DO. El tiempo y la memoria, Madrid, Cátedra/Filmoteca Española, 2000.

TUSELL, J., Sueiro, S., Marín, J. Mª., Casanova, M., El régimen de Franco (19391975). Congreso Internacional Madrid, Mayo 1993, Tomos I y II, Madrid, UNED, 1993.

b) Fuentes y otras publicaciones:

Archivo Sáenz de Tejada

Biblioteca Nacional

Boletín Oficial del Estado (BOE), 24 de abril de 1938 